social para garantir o vínculo social europeu contemporâneo. A existência de supranumerários sugere uma evolução do trabalho europeu em direção a uma estrutura análoga ao subdesenvolvimento do trabalho brasileiro.

Para a sociedade brasileira, a reestruturação contemporânea do trabalho implicou a renovação de sua estrutura hierárquica moderna. A análise da trajetória ocupacional de trabalhadores brasilienses da construção civil entre 1992-2003, por meio do indicador de capital ocupacional, identificou a precarização generalizada das ocupações não-regulamentadas como uma das características da reestruturação contemporânea do trabalho no Brasil. A manutenção e aprofundamento da estrutura de subdesenvolvimento e segmentação de sua divisão do trabalho ensejam indagações sobre as tendências da autoprodução contínua da sociedade brasileira contemporânea, em particular no que tange aos limites da ideologia da cordialidade e de sua estrutura de subdesenvolvimento e segmentação sistêmica.

Palavras-chave: Brasil, cidadania, trabalho, trajetórias ocupacionais, capital ocupacional, Brasília, construção civil, Émile Durkheim.

\title{
Programa de Atendimento ao Superdotado da Secretaria de Estado de Educação do Distrito Federal (1991-2002): inclusão social ou tergiversação burocrática?
}

Marília Gonzaga Martins Souto de Magalhães

Curso: Doutorado em Sociologia

Data da defesa: 4 de agosto de 2006

Orientador: Prof. Dr. Lúcio de Brito Castelo Branco 


\section{Resumo}

O presente estudo analisa o Programa de Atendimento ao Superdotado da Secretaria de Estado de Educação do Distrito Federal, no período de fevereiro de 1991 a dezembro de 2002, procurando verificar se as ações desenvolvidas nos processos de encaminhamento, avaliação e atendimento ao aluno superdotado favoreciam sua inclusão social.

Lançando mão de entrevistas com gestores, professores e ex-alunos do Programa e, também, de estudos documentais, a pesquisa constatou a necessidade e a importância de se identificar e de proporcionar ao aluno superdotado um programa especializado como forma de favorecimento ao seu ajustamento e inclusão social. A predominância de alunos do sexo masculino no universo de alunos pesquisados foi notória, comprovando um alto contingente de superdotados deste sexo.

Com relação à necessidade de oferecimento de um programa especializado para superdotados, constatou-se que ela existe, uma vez que, no ensino regular, tais alunos não são identificados por seus professores e, portanto, não são estimulados da maneira mais adequada.

O estudo verificou divergências entre os profissionais da área no aspecto referente à gestão de um programa para superdotados subordinado ao mesmo órgão que atende os deficientes. O mesmo foi constatado no aspecto alusivo a uma possível correlação existente entre as limitações que o Programa de Atendimento ao Superdotado da Secretaria de Estado de Educação do Distrito Federal enfrenta e as Diretrizes Norteadoras desta área emanadas do MEC, visto que, nessas diretrizes, percebe-se uma priorização das ações voltadas para os alunos que apresentam alguma deficiência em detrimento dos programas para superdotados, sobretudo na questão de alocação de recursos e reconhecimento da superdotação.

Palavras-chave: superdotação, inclusão, atendimento, educação. 